\title{
OOPEN ACCESS
}

Finance \& Accounting Research Journal

P-ISSN: 2708-633X, E-ISSN: 2708-6348

Volume 4, Issue 1, P.No. 1-13, January 2022

DOI: $10.51594 /$ farj.v4i1.284

Fair East Publishers

Journal Homepage: www.fepbl.com/index.php/fari

\section{CAPITAL ADEQUACY AND DEPOSIT MONEY BANK'S RETURN ON ASSET (ROA) IN NIGERIA}

\author{
Akinroluyo, Bankole Isaac ${ }^{1} \&$ Adeoti J. O \\ ${ }^{1}$ Department of Business Administration, Faculty of Management Sciences, \\ Nnamdi Azikiwe University Awka, Anambra State, Nigerial \\ ${ }^{2}$ Department of Business Administration, Faculty of Management Sciences, \\ University of Ilorin, Ilorin
}

*Corresponding Author: Akinroluyo, Bankole Isaac

Corresponding Author Email: bi.akinroluyo@unizik.edu.ng

Article Received: 25-12-21

Accepted: 10-01-22

Published: 14-01-22

Licensing Details: Author retains the right of this article. The article is distributed under the terms of the Creative Commons Attribution-Non Commercial 4.0 License (http://www.creativecommons.org/licences/by-nc/4.0/) which permits non-commercial use, reproduction and distribution of the work without further permission provided the original work is attributed as specified on the Journal open access page.

\begin{abstract}
This study investigated capital adequacy and Deposit Money Bank's (DMB) Return on Asset (ROA) in Nigeria in which the effect of capital to asset ratio on bank's profit margin and the relationship between solvency and asset turnover was examined. The study population of the study comprised Nigeria deposit money banks listed on the floor of Nigeria Stock Exchange as at 2021. Sample of bank selected was Zenith Plc, Guaranty Trust Bank Plc (GTB), First Bank Nigeria Limited, Access Bank Plc, and United Bank for Africa Plc based on global ranking order and the fact that they are listed on Nigeria Stock Exchange. To determine the effect of capital adequacy on banks performance, Ordinary Least Square (OLS) regression model was employed the data collected within the period of 2006-2020. The findings of this study revealed coefficient of 0.080034 implies $1 \%$ change in capital to asset ratio would lead to $8 \%$ increase change in profit margin ratio and p-value of 0.042223 shows that CTA has statistical significant effect on profit margin of the selected banks within the period under study; coefficient of 0.04587 implies $1 \%$ change in solvency would lead to $4.58 \%$ change in asset turnover of the selected DMBs under the period studied, p-value of 0.0000611 shows that SOLV has statistical significant relationship with ATU of the selected banks within the period
\end{abstract}


under study. The study recommends bank decision makers should give consideration for its solvency status and capital to asset ratio when investigating factors affecting bank's actualization objective. In addition, DMBs in Nigeria should ensure that they maintain above minimum capital to asset ratio level in order to guarantee an efficient profit margin. Also, the ability of DMBs to meet their short and medium term financial obligations must be fortified in order to keep the performance at per.

Keywords: Capital Adequacy, Return on Asset, Capital to Asset Ratio, Solvency, Profit Margin and Asset Turnover.

\section{INTRODUCTION}

Over the years, the banking industry in Nigeria has been known in the world of business to make available financial capital for the business community as well as individual customers and as such, they do this with the expectation of attaining intended return rates returns on credit extension for a specified period, and eventually possessing their initial investment with profits. Deposit money banks function as middle men by receiving left over money and loaning it to investors to carry out transactions. Through the provision of money to the public, deposit money banks invest in economy growth (Kallberg \& Udell, 2015). Most revenue is generated by banks by availing loans to clients and this major source of their income comes with great risk if not well managed. This has been a major source of income for deposit money banks as they tend to make their income as well through the credit leasing to the organizations and individuals who require funds as it is pertinent to note that deposit money banks has a key function they play in the economic resource distribution of countries.

Deposit money banks are like a lifesaver in developing countries of the world because that is the surest way to get money across to those that need it for pay which is interest. Deposit money banks in developing economies are synonymous to arteries used to transport blood in the human body, especially in Nigeria as it is attributed to for more than $90 \%$ of their economic resources (Rwayitare, Shukla \& Ruhara, 2016). Bank exists not exclusively to acknowledge deposit from the savers yet additionally to concede credit facilities. This intermediation capacity of banks leads to various kinds of risks with various extents and level of causes on bank performance, for example, credit risk, liquidity risk, market risk, legal risk, foreign exchange risk, solvency risk and operational risk. Among these dangers, credit risk is one of the most well-known reasons for bank failures and the accomplishment of their business relies upon precise estimation and proficient administration of credit risks more than some other risks (Kolapo, Ayeni, \& Oke, 2012).

The survival of deposit money banks especially in credit risk management area are dependent on many factors such as liquidity ratio, cost efficiency and capital adequacy ratio among others. Capital adequacy ratio is the main thrust of this study to know how it enhance performance of deposit money banks in the area of return on asset. On this note, Jeff (2015) gave an overall outline of capital necessities for banks and monetary establishments by thinking about the return on assets ratio as the essential component of the administration of bank capital; additionally he showed that there is no distinction in the capital norms of banks and monetary organizations. Santamero and Watson (2015) led a review named "determining an optimal capital standard for banking industry" they showed that by establishing hard guidelines for 
capital market, banks have decreased their credits that prompts breakdown of productive investments.

Risk in DMBs is also measured by the level of capital adequacy. Capital adequacy is a fundamental aspect of risk management and control function in a financial institution, including DMBs. Capital adequacy is an indicator of the financial strength of a bank revealed by how well the bank's capital is able provide cushion to its risky loans. According to Mendoza and Rivera (2017), a good capital adequacy ratio enhances the financial stability of banks and improves their efficiency in the protection depositors' funds. The quality and strength of capital influence profitability. This is because the low level of Capital Adequacy Ratio (CAR) leads to higher borrowing cost which lowers profit. Capital adequacy, therefore, impacts banks' performance. The financial stability report by the Central Bank of Nigeria (CBN, 2017) documented that CAR came down by 3.3\% for the period covering December 2016 to June 2017. Furthermore, the magnitude of risky assets in relation to first-tier capital stood at $16.3 \%$ in December 2016, while it came down to $12.4 \%$ in June 2017, representing a decline of 3.9\%. Capital to asset ratio which is an instrument for ensuring that the amount of capital owned by the bank could surmount the asset so as to ensure efficiency of performance. On this note Zheng et al. (2012) affirmed that banks that has enough capital adjust their capital buffer and risk positively, while for low capital banks, the relationship is negative. This is an indication that DMBs with low capital to asset ratio will find it gruesome to withstand and manage their credit risk effectively and efficiently which may literally affect return on asset as a measure of banks' performance. In addition, Odonkor et al. (2016) supplemented that macroeconomic factors additionally assume a significant part in risk tasking conduct of the banks while Okafor (2011) expressed that assuming enough capital isn't sufficient. It is considered fitting that banks should recognize risk which equivalent with the cash-flow to upgrade bank efficiency. Al-Kayed et al. (2014) presumed that capital structure is especially powerful in deciding the exhibition of the banks and higher capital effects the presentation emphatically while Seenaiah et al. (2015) viewed operating profit as emphatically connected with ROA and ROE, while NPA and NIM are contrarily related.

It is quite eminent to put to record that the survival of deposit money banks lies on their ability to provide credit facilities efficiently by mitigating the associated credit risks. It is not farfetched that many banks collapsed in the past because the proportion of non-performing loan outweighs the performing ones and of the various risks the banking industry is prone to, the most cumbersome to contain is how to manage credit risk due to the fact that it is not only dependent on collaterals and defaults but also has to do with general macroeconomics conditions. Specifically, their constant and continuous volatility which is a huge determinant of banks' performance. On the same note, the survival of Deposit Money Banks (DMBs) is largely dependent or determined by how efficient deposit money banks can efficiently handle their credit risk.

It is quite pertinent to know that banks that could not meet up with certain capital ratio will be at risk of folding up which sometimes resulted to merger or acquisition. Studies such as ELMaude, Abdul-Rahman, \& Ibrahim (2017); Islam, Sarker, Rahman, Sultana and Prodhan (2017); Okoye, Ikechukwu, Leonard, Chinyere, and Christian (2017); and Udom and Eze (2018), were inconclusive on the impact of capital adequacy ratios on bank performance which makes this study to expect to add to the current writing by examining capital adequacy and 
Nigeria deposit money bank's return on asset (ROA). By so doing, the study walks in the waske of Arellano and Bond (1991), Arellano-Bover (1995), and Blundell-Bond (1998); Blundell, et al, (2000), Davidson and Mackinnon (2004), Bun and Windmeijer (2009) Alege and Ogundipe (2013) and Medee and Ikue- John (2017) to gauge the unique the effect of capital adequacy ratios on return on asset of selected internationalized DMBs in Nigeria from 2006 to 2020. All these studies are not done in the present locale and the banks involved are different which creates a gap to be covered in this study by looking into capital adequacy and Nigeria deposit money bank's return on asset (ROA) in Nigeria within 2006-2020. The main purpose of this study is to investigate capital adequacy and Nigeria deposit money bank's return on asset (ROA) while the specific objectives of this study are to:

1. investigate the effect of capital to asset ratio on bank's profit margin.

2. examine the relationship between solvency and asset turnover of bank.

\section{LITERATURE REVIEW}

\section{Credit Risk Management}

Credit risk management is a basic part of an extensive way to deal with risk and is essential for long-term success of deposit money banks. Overseeing credit risk is one of the multi-layered assignments and should be possible through different methodologies. Afriyie and Akotey (2012) characterize credit risk management as an organized way to deal with vulnerabilities through risk appraisal; moderate danger utilizing administrative assets; techniques improvement like moving risk to another party, preventing risks, decrease the adverse consequence of the risk, tolerating a few or every one of the results of specific risk. Gestel and Baesens (2009) acknowlege credit risk management as an interaction that implies the identification of expected risks, the proper treatment and the genuine execution of risk models. Besides, as indicated by Basel Committee on Banking Supervision, (2009), credit risk management is a bunch of sound actions, for example, setting up a proper credit risk climate, working under a durable credit-conceding process, keeping a fitting credit risk estimation and checking process and guaranteeing sufficient powers over credit risks.

\section{Capital Adequacy Ratio}

Capital adequacy is a key concept regarding business particularly in banking business because of its role in providing cover for its risky assets. Capital adequacy measures how much of a bank's capital represented by its net worth can allay the unfavorable effects of its risky loans (Economic Times Bureau, 2010), it mitigates widespread distress in the banking industry and spurs business exertion and performance (Ezike \& Oke, 2013) and increases credit risk when it is low (Mukhtarov \& Mammadov, 2018). In the banking sector, capital is composed of two types which are first-tier capital and second tier capital (Basel Committee on Banking Supervision, 2015).

Mendoza and Rivera (2017) explains that the first-tier capital is able to sop up losses which is not bad enough to force the bank to close operations, while the second-tier capital absorbs losses when the operations of the bank is in the process of liquidation and lowers the safety depositors' fund. Bessis, (2011) posited that sufficient capital guides recapitalization in that it arises to address the issue of individual banks in type of expanding the base settled up capital so that banks can complete their activity effectively with their clients. This is a method of remedying the wide spread trouble of the financial area. Recapitalization as indicated by Ochei (2010) is the demonstration of netting up the drawn out capital of a bank to the level essentially 
needed by the money related specialists and to guarantee the security of investors' asset accessibility of capital decides the greatest degree of resources.

An audit of banks' prudential proportions in 2015 showed that the business normal average capital adequacy ratio (CAR) remained at $17.7 \%$, contrasted and the $15.9 \%$ at end of December 2014. The improvement in the CAR was ascribed, generally, to increment in the passing capital of banks coming about because of extra capital raised during the year and promoted held income. Also, the business normal liquidity ratio (LR) was $48.6 \%$, contrasted and $45.7 \%$ at end-December 2014, and surpassed the recommended least LR of $30.0 \%$ by 18.6 rate focuses. The asset quality of banks, estimated by the proportion of non-performing credits to industry complete, weakened as it expanded from 2.9 percent at end-December 2014, to 4.9 percent in 2015. The decrease in credit quality mirrored the unfriendly impact of late macroeconomic turns of events, for example, falling worldwide oil costs on banks' credit portfolios (CBN, 2015).

As per Olalekan and Adeyinka (2013), the base proportion of money to add up to chance weighted resources ought to stay at $10 \%$ as recommended in round BSD/11/2003 gave on 4 August 2003. Further, somewhere around 50\% of a bank's capital ought to contain settled up capital and stores, while each bank ought to keep a proportion of at the very least 1:10 between its changed capital assets and absolute credit net of arrangements. Thus, store cash banks in Nigeria are urged to keep a more elevated level of capital which is similar with their risk profiles.

The significance of capital sufficiency lies in the way that it helps in spreading the expense of reasonable business lead and hinders the criminally minded. VanRoy, (2006) clarifies that a bank requires capital adequacy for the very reasons that different organizations require capital since banks manage others' money. Different examinations have expressed that high capital strength proportions bring about better bank evaluations (Laruccia and Revoltella, 2000; Pasiouras et al., 2007; Poon et al., 2009; Poon and Firth, 2005; Van-Roy, 2006).This suggests that all around promoted banks will generally gain higher bank FSRs. Subsequently the requirement for capital ampleness for banks is a squeezing issue in Nigeria as well as to an exceptionally huge degree in different nations universally.

\section{Capital-to-Asset Ratio}

The capital-to-asset ratio ascertains an organization's resources and funding to decide if there is sufficient cash-flow to cover the resources, communicated as a rate. Valuable to controllers, business chiefs and financial backers, the money to-resource proportion reveals insight into an organization's monetary status and how it thinks about to comparable organizations (Danielle, 2020). In banking, the funding to-resource proportions are utilized in more than one way, including the variable capital resource proportion and capital sufficiency proportion (CAR). The variable capital resource proportion is a technique for credit control set by the national bank that the variable capital resource proportion applies to store cash banks and decides the proportion of capital a business bank ought to have to its complete resources (Danielle, 2020). The capital ampleness proportion estimates how the bank's accessible capital identifies with the danger weighted credit openness. Additionally, alluded to as the capital-to-risk weighted assets ratio (CRAR), this computation is utilized to secure contributors and advance dependability. 
On this note, Allen and Carletti (2010) expressed that the cost mirrors the essentials of resources and can be confided in a proficient market. Nonetheless, assuming the value neglects to do as such, it might downplay or exaggerate the essentials of resources and become hard for banks to decide the worth of resources. Banking is a profit-looking for industry and every one of the information sources and results should be measured. Subsequently, the cost of resources held by banks can be utilized to quantify their capacity to produce future income.

\section{Return on Asset (ROA) and Banks Performance}

One of profitability ratios is Return on Assets (ROA). In the investigation of financial summaries, this proportion is regularly featured, on the grounds that it can show banks accomplishment to make benefits. ROA can gauge the organization capacity to create benefits in the past to then be projected later on. Assets being referred to are generally organization properties, gotten from the actual capital or from unfamiliar capital that has been changed over into organization resources utilized for corporate maintainability. As indicated by Brigham and Houston (2001), return on assets (ROA) is determined by looking at accessible net benefit for common investors to add up to resources.

Available net profit for common shareholders

ROA $=$ Total assets

Higher ROA esteem demonstrates better organization execution, due to better yield on venture rate. "This worth mirrors the organization's profit from all resources (or subsidizing) gave to the organization" (Wild, 2005). Elements influencing on Return on Assets are (a). Liquidity Ratio is a proportion to gauge an organization's capacity to meet its momentary liabilities, determined by contrasting its present resources and current liabilities (b). Asset Management Ratio is "The asset management ratio; gauges how viably the organization deals with its resources" (Brigham and Houston, 2001). (c). Debt Management Ratio is asset management ratio to know the degree of organization's capacity to meet its drawn out commitments (obligation) used to back all organization exercises.

ROA is a benefit proportion that demonstrates the organization's capacity to effectively create benefits from the all assets claimed. The more prominent the mean presentation of the organization's ROA, the better benefit of the organization, on the grounds that the pace of return progressively producing benefits versus the somewhat little resources (Kim and Kim 2010). Return on resources is an inward component that is utilized to gauge the viability of the organization in producing benefits with the utilization of resources claimed (Wild, 2005). Exceptional yield on resources demonstrates how well the resources are overseen by the organizations to bring benefit for every one dollar of assets that has been contributed to the organization (Gul, 2011).

\section{Solvency Risk in the Banking Industry}

Solvency of a bank decides how speedy it could respond to its financial commitments occasionally. This is on the grounds that when banks are hit by a shock adequately huge to possibly think twice about solvency, it is viewed as an extraordinary risk which is appropriate to support proactively after some time. This, thusly, will make it awkward to give financing at rates like those acquired pre-shock. However on the other hand, solvency risk can shoot up the expense of subsidizing which addresses a terrible sign for the bank (Acharya and Mora, 2015; Hasan et al. 2016; Gambacorta and Shin, 2016). Additionally, in the event that banks experience an industrious expansion in subsidizing costs, there will be a weakening on the 
capacity of the bank to create a decent gain edge and for manageability purpose, the premise may be raised doubt about. This may at last expand the solvency risk of the organization.

Concisely, as confirmed by Beau et al. (2014), Babihuga and Spaltro (2014), higher financing expenses can expand solvency risk of DMBs, subsequently achieves a negative criticism circle can arise between the two wellsprings of stress. Solvency risk and financing costs are accordingly two powers that can connect with and feed upon one another. This communication drives criticisms that macroprudential stress tests should give close consideration to, as underlined in ongoing calls for "making stress tests more macroprudential" (BCBS, 2015). In this paper, we concentrate on the connection between solvency risk and funding costs utilizing two proprietary data sets of the Bank of Korea that collect detailed balance sheet information and marginal funding costs at the quarterly frequency for Korean commercial banks.

\section{Theoretical Framework}

Capital ampleness is a genuinely new region in deposit money banks' risk management particularly in developing nations. In this review, the expected income theory clarified the hypothetical supporting as it identified with banks performance. This theory relies upon loan portfolio as liquidity source. Generally, banks' liquidity can be arranged on the off chance that booked loan payments depend on pay of the borrower at a moment. Hence, the hypothesis perceives the influence of the maturity structure of the loan and investment portfolio on liquidity position of banks (Kosmidou, 2008; Ezike and Oke, 2013). Very much like other comparative speculations, anticipated income theory significant blemish is in the installment loan reimbursements. Since installment loan repayments gives normal stream of liquidity, they may not be satisfactory in gathering unstructured crises as far as money necessities in the financial framework. Thus, Bosede, Olowe and Uwuigbe (2013) thought the banks the executives expected to keep up with some capital as pad to ingest vulnerability in the business climate. The 2008/2009 financial crisis advocated this theory and as the climate turns out to be more intricate the need to comprehend the fundamentals of this theory is adept and this review based upon such conviction.

\section{METHODOLOGY}

This research adopted descriptive research of a panel data type which explored the degree of association between variables under consideration. The study used secondary data which is the financial statements of all the sampled deposit money banks for the study, for the period of fifteen years (2006-2020) in other to measure recent development rate of this institution. Ordinary Least Square (OLS) regression model was employed using E-views as in Padachi, (2006) and Deloof, (2003). The model for this study accepts a basic connection between impacts of credit risk management on deposit money banks performance in Nigeria. The review follows a comparative examination strategy utilized by Ajayi and Ajayi (2017), Kolapo, Ayeni and Oke (2012). For instance Kolapo, Ayeni and Oke (2012) econometric model are stated as: The hypotheses are mathematically expressed as follows;

\footnotetext{
$\mathrm{PRM}=\mathrm{a}+\beta_{1} \mathrm{CATI}+\mathrm{e} \ldots \ldots \ldots \ldots$ (1)

Where:

PRM= Profit Margin

$\mathrm{a}=$ Constant Variable

$\beta(1)=$ the slopes of CAT

$\mathrm{e}=$ Residuals or Error term
} 


\author{
$\mathrm{ATO}=\mathrm{a}+\beta_{1} \mathrm{OSOLI}+\mathrm{e} \ldots \ldots . . . .$. (2) \\ $\mathrm{ATO}=$ Asset Turnover \\ $\mathrm{a}=$ Constant Variable \\ $\beta(1)=$ the slopes of $X$ \\ $S \boldsymbol{O L}=$ Solvency \\ $\mathrm{e}=$ Residuals or Error term
}

\title{
RESULTS
}

The information for this review are panel and pooled in nature on the grounds that the variables indicated in the above models covered all the 5 sampled DMBs for a time of 15 years (2006 2020), thus, Panel Least Square method was utilized as econometric analysis for this research. Nonetheless, the logical justification to decide the particular Panel Least square regression strategies to be embraced is the Hausman test for irregular impacts. As indicated by Gujarati and Porter (2009), the null hypothesis underlying the Hausman test is that the Fixed Effect Model (FEM) and Random Effect Model (REM) estimators don't vary considerably. Assuming the null hypothesis is dismissed (when the chi-square measurements of the cross sectional random test is significant), the end is that the REM isn't proper, for this situation the FEM is preferred to REM.

Table 1 contains the spellbinding measurements of the factors of Profit Margin (GM), Capital to Asset Ratio (CTA), Asset Turnover (ATU) and Solvency (SOLV). As per the outcomes acquired from Table 1, the coefficient of skewness is positive for every one of the variables which means that the distribution of the variables is pulled to one side. To research the kurtosis measure, in the event that the obtained value is positive, there is a lower scattering of information around the mean, while a negative worth demonstrates a more elevated level of dispersion of information around the mean. The zero value of the kurtosis coefficient shows a normal distribution. The investigation of the kurtosis measure proposes that the probability distribution of the information is more extended in comparison with the normal distribution (for example there is a lower level of dispersion). Likewise, the probability of the Jarque-Bera statistics in table 1 shows every one of the variable have a probability greater than 5\%. Thusly, the null hypothesis is accepted, and it is concluded that the distribution of the research data is normal.

Table 1

Descriptive Statistics Variables of Profit Margin (GM), Capital to Asset Ratio (CTA), Asset Turnover (ATU) and Solvency (SOLV)

\begin{tabular}{|c|c|c|c|c|}
\hline & PM & CTA & ATU & SOLV \\
\hline Mean & 0.296133 & 0.139467 & 0.096400 & 1.266565 \\
\hline Median & 0.290000 & 0.130000 & 0.090000 & 1.204456 \\
\hline Maximum & 0.640000 & 0.310000 & 0.200000 & 3.212697 \\
\hline Minimum & 0.030000 & 0.050000 & 0.050000 & 0.988025 \\
\hline Std. Dev. & 0.144446 & 0.043802 & 0.025236 & 0.299374 \\
\hline Skewness & 0.656498 & 1.056950 & 1.573997 & 4.656285 \\
\hline Kurtosis & 3.137524 & 5.151146 & 7.178680 & 27.90527 \\
\hline Jarque-Bera & 5.446466 & 28.42500 & 85.53511 & 2209.364 \\
\hline Probability & 0.065662 & 0.090001 & 0.243000 & 0.113000 \\
\hline Sum & 22.21000 & 10.46000 & 7.230000 & 94.99236 \\
\hline Sum Sq. Dev. & 1.543979 & 0.141979 & 0.047128 & 6.632232 \\
\hline Observations & 75 & 75 & 75 & 75 \\
\hline
\end{tabular}

Source: Researchers, 2021 


\section{The Effect of Capital to Asset Ratio on Bank's Profit Margin}

The study considered random effect appropriate for the analysis of capital to asset ratio (CTA) and bank's profit margin (PM) since the Hausman test' p-value of 0.6577 exceeds 0.05 significance level. Coefficient of 0.080034 implies $1 \%$ increase change in capital to asset ratio would lead to $8 \%$ increase change in profit margin ratio. Similarly, t-statistics of 2.056182 with p-value of 0.043 and f-statistics of 4.274948 with p-value of 0.042223 shows CTA has statistical significant effect on PM of the selected banks within the period under study. The result implies that capital to asset ratio is a significant variable that determines the performance of DMBs in Nigeria which must not be taken with levity.

\section{Table 2}

Panel Data Result of Effect of Capital to Asset Ratio on Bank's Profit Margin

\begin{tabular}{ll}
\hline FIXED EFFECT & RAMDOM EFFECT \\
\hline Coefficient: 0.074077 & Coefficient: 0.080034 \\
t-statistics: 1.798907 & t-statistics: 2.056182 \\
Prob.: 0.0764 & Prob. 0.0433 \\
R-squared: 0.344893 & R-squared: 0.055321 \\
Adjusted R-square: 0.297422 & Adjusted R-square: 0.042380 \\
F-statistics: 7.265275 & F-statistics: 4.274948 \\
Prob. (F-statistics): 0.000016 & Prob. (F-statistics): 0.042223 \\
Durbin-Watson: 1.485595 & Durbin-Watson: 1.418652 \\
Hausman Test Prob. 0.6577 & Hausman Test Prob. 0.6577 \\
\hline \multicolumn{2}{c}{ Source: Researchers, 2021 }
\end{tabular}

Source: Researchers, 2021

\section{Relationship between Solvency and Asset Turnover of Bank}

The study also considered random effect appropriate for the analysis of relationship between solvency (SOLV) and asset turnover (ATU) since the Hausman test' p-value of 0.1516 shown in table 1 exceeds 0.05 significance level. Coefficient of 0.04587 implies $1 \%$ change in solvency would lead to $4.58 \%$ change in asset turnover of the selected DMBs under the period studied. Furthermore, t-statistics of 3.599273 with p-value of 0.00006 and f-statistics of 12.83416 with p-value of 0.0000611 shows that SOLV has statistical significant relationship with ATU of the selected banks within the period under study.

Table 3

Panel Data Result of Effect of solvency on Asset Turnover

\begin{tabular}{cc}
\hline FIXED EFFECT & RAMDOM EFFECT \\
\hline Coefficient: 3.379236 & Coefficient: 0.045871 \\
t-statistics: 2.212008 & t-statistics: 3.599273 \\
Prob.: 0.0303 & Prob. 0.0006 \\
R-squared: 0.203608 & R-squared: 0.149523 \\
Adjusted R-square: 0.145898 & Adjusted R-square: 0.137872 \\
F-statistics: 3.528148 & F-statistics: 12.83416 \\
Prob. (F-statistics): 0.006728 & Prob. (F-statistics): 0.000611 \\
Durbin-Watson: 0.847669 & Durbin-Watson: 0.824911 \\
Hausman Test Prob. 0.1516 & Hausman Test Prob. 0.1516 \\
\hline
\end{tabular}

Source: Researchers, 2021

\section{Discussion of Findings}

Capital adequacy and return on assets of deposit money banks in Nigeria was examined in this study. The study found positive and significant relationship between capital to asset ratio on 
firm's profit margin which is an indication that firm's ability to actualize shareholders' profit maximization objective has significant connection with bank's ratio of owners' capital to total asset. This is an indication that capital adequacy has significant impact on DMBs' return on asset. The result is in tandem with that of Mendoza and Rivera (2017) that a good capital adequacy ratio enhances the financial stability of banks and improves their efficiency in the protection depositors' funds. In the same vein, Zheng et al. (2012) maintained banks with adequate capital adjust their capital buffer and risk positively, while for low capital banks, the relationship is negative. The study also found positive and significant relationship between solvency and the selected bank's asset turnover within the period under study. This shows that bank's ability to meet up with its short term obligations has influence on its ability to actualize shareholders' profit maximization objective. The finding corroborates with that of Beau et al. (2014), Babihuga and Spaltro (2014) that higher funding costs can increase solvency risk of DMBs, therefore brings about a negative feedback loop on the yield of asset. The proxies of capital adequacy and that of ROA were found that to be affecting each other in this study. This implies the effect of capital adequacy on performance of deposit money banks in Nigeria. This result is in line with that of Okoye, Ikechukwu, Leonard, Chinyere, \& Christian, (2017) whom reported that the indicators of capital adequacy positively impact on deposit money banks performance in Nigeria within 2010 and 2015.

\section{CONCLUSION}

This study concluded that capital to asset ratio has significant impact on profit margin while solvency on the other hand had significant effect on asset turnover. Generally, capital adequacy had significant effect on return on asset of DMBs in Nigeria. This indicates that it essential for DMBs to ensure that there is enough capital to ensure that the credit risk is hedged to ensure that there is increase on DMBs performance indicators.

\section{Recommendation}

The study recommends bank decision makers should give consideration for its solvency status and capital to asset ratio when investigating factors affecting bank's actualization objective. In addition, DMBs in Nigeria should ensure that they maintain above minimum capital to asset ratio level in order to guarantee an efficient profit margin. Also, the ability of DMBs to meet their short and medium term financial obligations must be fortified in order to keep the performance at per.

\section{References}

Afriyie, H., \& Akotey, J. (2011). Credit risk management and profitability of selected rural banks in Ghana (1-18). Catholic of Ghana

Ajayi, A.P., \& Ajayi, L.P. (2017). Assessment of the Influence of Lagos Bus Rapid Transit Scheme (BRT-Lite) on Road Traffic Crashes (RTC) on Lagos Mainland-Island Corridor. The Open Transportation Journal, 11, 102-109.

Alege, P., \& Ogundipe, A. (2013). Environmental quality and economic growth in Nigeria: A fractional cointegration analysis. International Journal of Development and Sustainability, 2, 2168-8662.

Al-Kayed, L.T., Zain, S.R.S.M., \& Duasa, J. (2014). The relationship between capital structure and performance of Islamic banks. Journal of Islam Accounting and Business Research, 5(2), 158-181. 
Allen, F., \& Carletti, E. (2010). An Overview of the Crisis: Causes, Consequences, and Solutions. International Review of Finance, 10, 1-26. 10.1111/j.14682443.2009.01103.x.

Arellano, M. O., \& Bover (1995). Another Look at the instrumental variable estimation of errorcomponents models. Journal of Econometrics, 6(8), 29-51.

Arellano, M., \& Bond, S. (1991). Some tests of specification for panel data: Monte Carlo evidence and an application to employment equations. The Review of Economic Studies, 58(2), 277-297.

Basel Committee on Banking Supervision. (2009). Guidelines: Corporate Governance Principles for Banks. Retrieved from https://www.bis.org/bcbs/publ/d328.pdf

Beau, C., M. Paustian, A. Penalver, T., \& Taylor. (2010). Monetary policy after the fall. in macroeconomic challenges: the decade ahead. Proceedings of the Federal Reserve Bank of Kansas City Economic Policy Symposium, Jackson Hole, Wyoming, August 26-28.

Bessis, J. (2011). Risk Management in Banking. John Wiley \& Sons.

Bluvndell, R., \& Bond, S. (2000). GMM estimation with persistent panel data: an application to production functions. Econometric Reviews, 19(3), 321-340.

Bosede, A. F., Olowe, O., \& Uwuigbe, O. R. (2013). Annotated Bibliography of Banking Industry Ethics and Performance.

Brigham, E. F., \& Houston, J. F. (2001). Financial management, translation by Erlangga publishing team. Eight Edition, II Book. Erlangga Publishing, Jakarta. Retrieved from https://onesearch.id/Author/Home?author=Houston\%2C+Joel+F.

Bun, M. J., \& Windmeijer, F. (2010). The weak instrument problem of the system GMM estimator in dynamic panel data models. The Econometrics Journal, 13(1), 95-126.

Danielle, N. E. L. (2020). Allocation of Risk In Public Private Partnerships In Information And Communications Technology. International Journal of Ebusiness and Egovernment Studies, 12(1), 17-32.

Deloof, M. (2003). Does working capital management affect profitability of Belgian firms? Journal of Business Finance \& Accounting, 30(3-4), 573-588.

EL-Maude, J. G., Abdul-Rahman, A., \& Ibrahim, M. (2017). Determinants of Non-Performing Loans in Nigeria's Deposit Money Banks. Archives of Business Research, 5(1), 74-88.

Ezike, J.E. \& Oke, M.O. (2013). Capital adequacy, standards, basle accord, and bank performance: The Nigerian experience. Asian Economic and Financial Review, 3, 146159.

Gestel, V. T. \&Baesens, Bart. (2008). Credit Risk Management: Basic Concepts: Financial Risk Components, Rating Analysis, Models, Economic and Regulatory Capital.

Gul, S. (2011). Factors affecting bank profitability in Pakistan. The Romanian Economic Journal, 14(39), 61-87.

Islam, M. A., Sarker, M. N., Rahman, M., Sultana, A., \& Prodhan, A. S. (207). Determinants of Profitability of Commercial Banks in Bangladesh. International Journal of Banking and Financial Law, 1(1), 001-011.

Jeff Ballweber, J. D. (2015). Incorporating uncertainty and decision analysis into a watersustainability index. Journal of Water Resources Planning and Management, 141(12), A4015007. 
Kallberg, J.G., \& Udell, G.F. (2015). The value of private sector business credit information sharing: the US case. Journal of Banking and Finance 27(3), 449-469.

Kolapo, T.F., Ayeni, R. K., \& Oke, M.O. (2012). Credit risk and commercial banks' performance in Nigeria: A panel model approach. Australian Journal of Business and Management Research, 2(2), 31-38.

Kosmidou, K. (2008). The determinants of banks' profits in Greece during the period of EU financial integration. Managerial Finance, 34, 146-159. DOI: $10.1108 / 03074350810848036$

Laruccia, E., \& Revoltella, D. (2000). Banking system stability in developing and transition economies: An analysis of the determinants of Moody"s bank financial strength rating. Working Paper, R2000-1, Banca Commercial eItaliana.

Medee, P., \& Ikue-John, N. (2017). Determinants of Foreign Direct Investment in ECOWAS Region: A System-GMM Approach. African Journal of Applied and Theoretical Economics Special Edition, 295-309.

Mendoza, R., \& Rivera, J. P. (2017). The Effect of Credit Risk and Capital Adequacy on the Profitability of Rural Banks in the Philippines. Scientific Annals of Economics and Business, 64(1), 83-96.

Mukhtarov, S., \& Mammadov, E. (2018). Factors that Increase Credit Risk of Azerbaijani Banks. Journal of International Studies, 11(2), 63-75.

Odonkor, T. A., Osei, B. A., Sjo, B. (2016) Risk taking, ownership and excess reserves in the Ghananaian Banking system. Journal of Emerging Market Finance, 15(2),147-168

Okafor, C. (2011). The effect of capital adequacy on banks performance. www.bvimsr.com.documentspublication2011V3N103.pdf Accessed 22 July 2016

Okoye, A. N., Ikechukwu, E., Leonard, N. C., Chinyere, O. J., \& Christian, O. E. (2017). Effect of capital adequacy on financial performance of quoted deposit money banks in Nigeria. International Conference on African Entrepreneurship and Innovation for Sustainable Development (AEISD): 841- 862.

Olalekan, A., \& Adeyinka, S. (2013). Capital Adequacy and Banks' Profitability: An Empirical Evidence from Nigeria. American International Journal of Contemporary Research, 87-93.

Padachi, K. (2006). Trends in working capital management and its impact of firm's performance: An analysis of Mauritian small manufacturing firms. International Review of Business Research Papers, 2, 45-58.

Pasiouras, F., \& Kosmidou, K. (2007). Factors influencing the profitability of domestics and foreign commercial banks in the European Union, Research in International Business and Research, 21, 222-237.

Poon, W. P. H., \& Firth, M. (2005). Are unsolicited credit ratings lower? International evidence from bank ratings. Journal of Business Finance and Accounting, 32(9-10), 1741-1771.

Poon, W. P. H., Lee, J. \& Gup, B. E. (2009). Do solicitations matter in bank credit ratings? Results from a study of 72 countries', Journal of Money, Credit and Banking, 41(2-3), 285-314.

Rwayitare, J. B., Shukla, J. \& Ruhara, C. (2016). Credit Risk and Commercial Bank Profitability in Rwanda. International Journal of Advance Research, 4(9), 294-325. 
Santamero, M., \& Watson, R. (2015). Determining an optimal capital standard for banking industry. Journal of Finance, 32(4), 1267-1282.

Seenaiah, K., Rath, B.N. \& Samantaraya, A. (2015). Determinants of bank profitability in the post- reform period: evidence from India. Global Business Review, 16(5s), 82s-92s

Udom, I. S., \& Eze, O. R. (2018). Effect of capital adequacy requirements on the profitability of commercial banks in Nigeria. International Research Journal of Finance and Economics, 165, 79-89.

Van-Roy, P. (2006). Is there a difference between solicited and unsolicited bank ratings and if so, why?' National Bank of Belguim Working Paper, 79. https://www.econstor.eu/bitstream/10419/111118/1/adbi-rp26.pdf

Wild, M. (2005). Atmospheric brown clouds: Impacts on South Asian climate and hydrological cycle. Proceedings of the National Academy of Sciences, 102(15), 5326-5333.

Zheng, C., Xu, T., \& Liang, W. (2012). The empirical research of banks' capital buffer and risk adjustment decision making. China Finance Reviews International, 2(2),163-179. 